\author{
제주도 석산 부산물인 화산토를 사용한 휽포장의 \\ 강도 및 시공 특성 \\ 홍 종 현 \\ 탐라대학교 토목환경공학과 \\ (2010년 10월 8일 접수; 2010년 11월 19일 수정; 2010년 12월 3일 채택)
}

\title{
Strength Characteristics of Soil Concrete Using Jeju Volcaniclastic and Construction Techniques \\ Chong-Hyun Hong*
}

Department of Civil and Environmental System Engineering, Tamna University, Jeju 697-703, Korea

(Manuscript received 8 October, 2010; revised 19 November, 2010; accepted 3 December, 2010)

\begin{abstract}
In this study, a series of soil concrete mixtures were tested for the compressive strength according to ratio of aggregate to binder, compaction energy, maximum aggregate size, ratio of silica fume to cement, and ratio of water to binder. The optimum mixing ratio of soil concrete mixtures composed of volcaniclastic, cement, silica fume, concrete polymer and water were analysed. The test results for optimum proportion were as follows ; (1)ratio of aggregate to binder was $4: 1$, (2) compaction energy level was level 2, (3)maximum aggregate size was $13 \mathrm{~mm}$, (4)ratio of silica fume to cement was $10 \%$, (5) ratio of water to binder was $25 \%$. Also, dry type construction techniques were applied using the optimum soil concrete mixture. From the results of this study, the compressive strength of soil concrete and construction techniques were suitable for making eco-friendly soil pavement.
\end{abstract}

Key Words : Compressive strength, Silica fume, Soil concrete, Soil pavement, Volcaniclastic

\section{1. 서 론}

국내 석산의 용도는 쇄석골재의 생산을 위한 것인 데 암석 채취과정에서 부산물인 토사나 석분 슬러지 가 발생된다. 특히, 제주도의 경우에는 지질학적 특수 성으로 인하여 현무암 석산에서 발생되는 토사의 양 은 상당히 많은 비중을 차지하며 대부분이 매립용으 로 이용되는 상황이다(Lee 등, 2006). 제주도 석산에

${ }^{*}$ Corresponding author : Chong-Hyun Hong, Department of Civil and Environmental System Engineering, Tamna University, Jeju 697-703, Korea

Phone: +82-64-735-2115

E-mail: jhhong@tnu.ac.kr
서 발생하는 토사는 화산활동에 의해 토사의 색상이 검은색 또는 적색을 나타내고 유기물이 매우 적다는 특 징이 있다. 이러한 특징은 다양한 질감의 디자인을 나타 낼 수 있는 훍포장의 소재로 적합하다(Hong, 2010; Hong 등, 2009).

도로포장에 있어서 시멘트 콘크리트 포장과 아스 팔트 콘크리트 포장은 경제성이 우수하고 강도와 내 구성이 높아 차도, 보행자도로, 주차장 등 다양한 용도 의 도로포장에 널리 이용되고 있다. 그러나, 공원, 사 찰, 문화재 지역과 같은 자연환경이나 문화적 특수성 이 있는 지역의 경우에는 황토포장이나 마사토포장과 같은 흙포장을 사용하는 경우가 증가하고 있다(Jung 
등, 2009; Jeong 등, 2007). 훍포장은 강도와 내구성이 낮은 단점이 있지만 현장의 흙을 사용하기 때문에 흙 포장의 질감이 주변경관과 조화를 이루는 장점으로 인해 디자인이 중요한 곳은 흙포장을 적용하는 경우 가 바람직하다. 우리나라 토양의 색채분포는 대부분 이 YR계열의 중명도/중채도와 YR계열 중명도/저채 도를 나타낸다(MIFAFF, 2009). 따라서, 도로가 자연 친화적인 분위기를 나타내기 위해서는 자연소재에 의 한 재료 자체색이나 주변의 훍을 콘크리트 제조과정 에 일정량 첨가하여 YR계열의 중명도/중채도 또는 중 명도/저채도인 흙의 질감을 나타내는 것이 바람직하 다. 흙포장의 경우 습식공법과 건식공법으로 구분되 는데 실무에서 적용하는 대부분의 흙포장 방식은 습 식공법이다. 그 이유는 건식공법의 경우 흙시멘트 배 합이 어렵고, 시공 후에는 표면박리와 균열발생과 같 은 하자 발생 가능성이 높기 때문에 현장에서는 습식 공법을 선호하고 있다. 그러나 흙포장의 디자인이 우 선시 된다면 습식공법 보다는 롤라 다짐 방식인 건식 공법이 자연환경에 더욱 적합한 질감을 나타낸다 (Hong, 2009).

본 연구에서는 건식 훍포장 공법이 가지고 있는 문 제점을 해결하고자 소일콘크리트의 압축강도와 내마 모성에 영향을 주는 결합재의 비율, 다짐에너지, 골재 최대치수, 혼화재의 비율, 배합수의 비율, 흙포장 표면 의 양생방법 등의 다양한 변수를 고려한 실험실 규모 의 강도실험과 현장 적용 시험시공을 실시하였다. 실 험결과, 본 연구에서 제안하는 고성능 흙포장 공법은 종래의 훍포장 공법에 비하여 높은 압축강도, 내마모 성, 내구성, 그리고 뛰어난 디자인 특성을 나타내는 것 으로 판단되었다.

\section{2. 재료 및 방법}

\section{1. 실험재료}

실험에 사용된 주재료는 화산토, 시멘트, 실리카흄,
콘크리트폴리머, 그리고 혼화제를 사용하였다. 화산 토는 제주도 안덕면 소재의 한창산업 석산에서 채취 한 화산쇄설물로서 Table 1에 물리적 특성을 나타내 었다. 절건밀도, 표건밀도, 흡수율은 KS F 2503, 액성 한계, 소성한계, 소성지수는 KS F 2303, 마모율은 KS F 2508, $0.08 \mathrm{~mm}$ 통과량은 KS F 2511의 방법으로 시 험하였다. 시험결과 화산쇄설물 골재는 일반적으로 사용하는 콘크리트 쇄석골재와 비교하여 밀도가 낮 고, 흡수율이 높고, 미립분이 많이 포함된 것으로 나타 났다. Table 2 는 화산쇄설물 골재를 흙의 개념으로 간 주할 때의 입도분석 결과를 나타낸 것이다. 입도시험 은 KS F 2302의 방법으로 시험하였고 모래질훍(SM) 에 해당되었다. 화산쇄설물 골재는 미립분을 상당량 함유한 흙의 개념으로 받아들여 천연칼라의 색상과 질감을 나타내는 디자인 중심의 콘크리트 제조에 주 구성성분으로 사용될 수 있다고 판단된다. 시멘트는 한라라파즈시멘트를 사용하였다. 실리카흄은 체코 (Czech) 공화국 소재의 AVAS에서 생산한 마이크로

Table 2. Soil properties

\begin{tabular}{cccc}
\hline Soil properties & $\begin{array}{c}\text { Fracti } \\
\text { on(\%) }\end{array}$ & Soil properties & Results \\
\hline \hline $\begin{array}{c}\text { Coarse gravel } \\
(19 \sim 75 \mathrm{~mm})\end{array}$ & 0.0 & $\begin{array}{c}\text { Maximum particle } \\
\text { size }\end{array}$ & $19 \mathrm{~mm}$ \\
\hline $\begin{array}{c}\text { Medium gravel } \\
(4.75 \sim 19 \mathrm{~mm})\end{array}$ & 16.0 & D60 & $1.6 \mathrm{~mm}$ \\
\hline $\begin{array}{c}\text { Fine gravel } \\
(2 \sim 4.75 \mathrm{~mm})\end{array}$ & 18.0 & D50 & $\begin{array}{c}0.94 \\
\mathrm{~mm}\end{array}$ \\
\hline $\begin{array}{c}\text { Coarse sand } \\
(0.850 \sim 2 \mathrm{~mm})\end{array}$ & 18.1 & $\mathrm{D} 30$ & $\begin{array}{c}0.21 \\
\mathrm{~mm}\end{array}$ \\
\hline $\begin{array}{c}\text { Medium sand } \\
(0.250 \sim 0.850 \mathrm{~mm})\end{array}$ & 16.2 & $\mathrm{D} 10$ & $\begin{array}{c}0.005 \\
\mathrm{~mm}\end{array}$ \\
\hline $\begin{array}{c}\text { Fine sand } \\
(0.075 \sim 0.250 \mathrm{~mm})\end{array}$ & 9.3 & $\mathrm{Uc}$ & 320.00 \\
\hline $\begin{array}{c}\text { Silt } \\
(0.005 \sim 0.075 \mathrm{~mm})\end{array}$ & 12.4 & $\mathrm{U} \mathrm{c}$ & 5.51 \\
\hline $\begin{array}{c}\text { Clay } \\
(\text { under } 0.005 \mathrm{~mm})\end{array}$ & 10.0 & $\mathrm{USCS}$ & $\mathrm{SM}$ \\
\hline
\end{tabular}

Table 1. Physical properties of volcaniclastic

\begin{tabular}{|c|c|c|c|c|c|c|c|c|}
\hline Test items & $\begin{array}{l}\text { Dry basis } \\
\text { density } \\
\left(\mathrm{g} / \mathrm{cm}^{3}\right)\end{array}$ & $\begin{array}{l}\text { Saturated surface - dry } \\
\text { basis density } \\
\left(\mathrm{g} / \mathrm{cm}^{3}\right)\end{array}$ & $\begin{array}{c}\text { Water } \\
\text { absorption } \\
(\%)\end{array}$ & $\begin{array}{l}\text { Liquid } \\
\text { limit } \\
(\%)\end{array}$ & $\begin{array}{l}\text { Plastic } \\
\text { limit } \\
(\%)\end{array}$ & $\begin{array}{l}\text { Plasticity } \\
\text { index }\end{array}$ & $\begin{array}{c}\text { Abrasion } \\
(\%) \\
\text { (GradingC) }\end{array}$ & $\begin{array}{c}\text { Finer than } \\
0.08 \mathrm{~mm}(\%)\end{array}$ \\
\hline Results & 1.73 & 1.99 & 14.96 & 27.6 & N.P & N.P & 44.8 & 27.0 \\
\hline
\end{tabular}

N.P is the abbreviation for Non-plastic. 
실리카를 사용하였다. 콘크리트폴리머는 독일 Wacker 에서 생산한 분산성 분말수지(dispersible polymer powders)를 사용하였다. 혼화재는 이코넥스(주)에서 생산한 고성능AE감수제를 사용하였다.

\section{2. 실험방법}

실험에 사용된 배합설계는 Table 3 에 나타내었다. 사전에 수차례 예비실험 한 결과, 화산토와 결합재의 혼합비율을 변수로 두고, 고성능 $\mathrm{AE}$ 감수제는 시멘트 의 $1 \%$ 비율, 그리고 물-결합재비는 $25 \%$ 에서 배합비 를 결정하고 실험을 수행하였다. 비빔은 $100 \ell$ 강제 식 팬타입 믹서(동아시험기, DA-305)를 이용하여 시 멘트와 화산토를 넣고 건비빔을 30 초간 행한 후, 고성 능 $\mathrm{AE}$ 감수제가 혼합된 물을 첨가하여 1 분 30 초간 비 빔을 행한 후 토출하였다. 압축강도를 시험하기 위한 공시체 제조는 Table 4 와 같은 다짐방법을 사용하였 다. 원주형 공시체의 경우, $2.5 \mathrm{~kg}$ 의 램머를 $30 \mathrm{~cm}$ 높 이에서 자유낙하 하여 화산토-시멘트 혼합물의 다짐 회수에 따라 해당하는 다짐에너지를 계산하였다. 공 시체의 양생은 온도 $20 \pm 5^{\circ} \mathrm{C}$, 습도 $70 \pm 10 \%$ 의 실험실 조건하에서 비닐을 이용한 기건양생을 하였다. 압축 강도 시험은 KS F 2405 콘크리트의 압축강도 시험 방 법에 따라 시험하였다

\section{3. 결과 및 고찰}

\section{1. 강도특성}

화산토와 결합재의 배합비율에 따른 압축강도 특 성을 Fig. 1 에 나타내었다. 압축강도는 결합재의 비율
이 높을 수 록 강도가 높아지지만, 경제성을 고려할 때 적당한 사용비율이 있다. Table 3 의 배합비율을 사용 하여 화산토/결합재의 비율이 3(3/1)일 때 압축강도가 $20.5 \mathrm{MPa}$ 로 나타났고, 4(4/1)일 때 $20.2 \mathrm{MPa}$ 이며, $5(5 / 1)$ 일 때 $15.6 \mathrm{MPa}$ 로 나타났다. 일반적으로 도로 포장에 있어서, 압축강도가 $18 \mathrm{MPa}$ 이상을 요구하기 때문에 화산토/결합재의 배합비율이 4(4/1)가 적당한 것으로 판단된다.

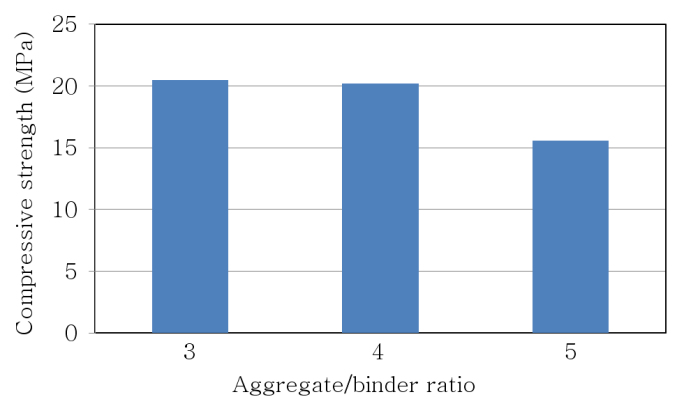

Fig. 1. 28-day sealed compressive strength versus ratio of aggregate to binder.

압축강도는 다짐에너지의 영향을 받는다. 따라서, Table 4와 같이 3 개의 다짐에너지 레벨로 나누어서 다 짐이 불량하게(Level 1), 다짐이 적당하게(Level 2), 다짐이 과도하게(Level 3) 실시하는 경우에 대한 소일 콘크리트 압축강도를 Fig. 2에 나타내었다. 압축강도 가 Level 1에서는 14.0 MPa, Level 2에서는 19.6 $\mathrm{MPa}$, Level 3에서는 20.2 MPa로 나타났다. Level 1 의 공시체는 다짐이 부족하여 전체적으로 다공질의

Table 3. Mixture proportion details

\begin{tabular}{ccccccc}
\hline $\begin{array}{c}\text { Mix } \\
\text { No. }\end{array}$ & $\begin{array}{c}\text { Aggregate-cement } \\
\text { ratio(weight })\end{array}$ & $\begin{array}{c}\text { Aggregate } \\
\left(\mathrm{kg} / \mathrm{m}^{3}\right)\end{array}$ & $\begin{array}{c}\text { Cement } \\
\left(\mathrm{kg} / \mathrm{m}^{3}\right)\end{array}$ & $\begin{array}{c}\text { Admixture } \\
\left(\mathrm{kg} / \mathrm{m}^{3}\right)\end{array}$ & $\begin{array}{c}\text { Water } \\
\left(\mathrm{kg} / \mathrm{m}^{3}\right)\end{array}$ & $\begin{array}{c}\text { Water-cement } \\
\mathrm{ratio}(\%)\end{array}$ \\
\hline \hline 1 & $3: 1$ & 1760 & 587 & 5.87 & 147 & 25 \\
2 & $4: 1$ & 1760 & 440 & 4.40 & 110 & 25 \\
3 & $5: 1$ & 1760 & 352 & 3.52 & 88 & 25 \\
\hline
\end{tabular}

Table 4. Compaction levels for cylindrical specimens

\begin{tabular}{ccccc}
\hline $\begin{array}{c}\text { Compaction } \\
\text { levels }\end{array}$ & $\begin{array}{c}\text { Compaction energy } \\
\left(\mathrm{cm}-\mathrm{kgf} / \mathrm{cm}^{3}\right)\end{array}$ & Number of blows & Rammer application & $\begin{array}{c}\text { Mold specimen } \\
(\mathrm{cm})\end{array}$ \\
\hline \hline 1 & 1.43 & 3 layers, 10 blows/layer & weight $2.5 \mathrm{~kg}$, height $30 \mathrm{~cm}$ & cylinder $10 * 20$ \\
2 & 2.86 & 3 layers, 20 blows/layer & weight $2.5 \mathrm{~kg}$, height $30 \mathrm{~cm}$ & cylinder $10 * 20$ \\
3 & 4.30 & 3 layers, 30 blows/layer & weight $2.5 \mathrm{~kg}$, height $30 \mathrm{~cm}$ & cylinder $10 * 20$ \\
\hline
\end{tabular}


공시체가 된 까닭에 압축강도가 낮게 나타났다. Level 2 이상에서는 공시체의 다짐이 충분한 것으로 판단된 다. 따라서, 최소한 Level 2 이상의 다짐에너지가 필요 한 것으로 사료된다.

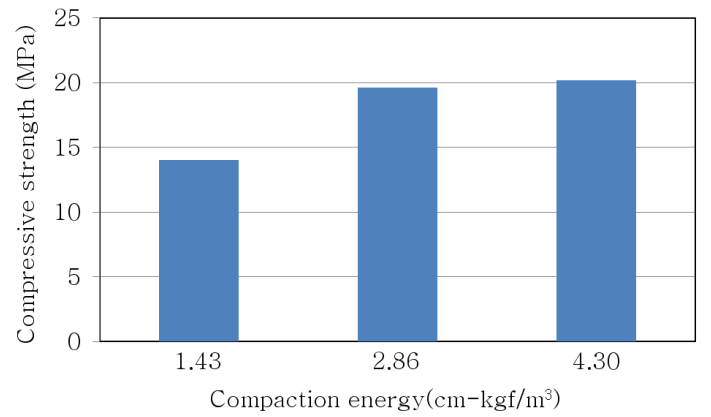

Fig. 2. 28-day sealed compressive strength versus compaction energy.

굵은골재의 최대치수를 $5 \mathrm{~mm}, 13 \mathrm{~mm}, 25 \mathrm{~mm}$ 로 설정한 소일콘크리트의 압축강도 특성을 Fig. 3 에 나 타내었다. 굵은골재 최대치수 $5 \mathrm{~mm}$ 의 잔골재만 $100 \%$ 사용하는 경우에는 물의 사용량이 조금만 많아 도 휽시멘트 혼합체의 점성이 높아서 혼합에 어려움 이 있었다. 굵은골재 최대치수 $13 \mathrm{~mm}$ 시험체는 $5 \mathrm{~mm}$ $70 \%$ 중량과 5 13 mm 30\% 중량을 혼합하여 사용한 경우로서 야외의 훍포장 용도로 적당하였다. 굵은골 재 최대치수 $25 \mathrm{~mm}$ 시험체는 $5 \mathrm{~mm} \mathrm{70 \%} \mathrm{중량과} \mathrm{5}$ $13 \mathrm{~mm} \mathrm{15 \%}$ 중량과 5 25 mm 15\% 중량을 혼합하여 사용하는 경우에는, 굵은골재의 최대치수가 $25 \mathrm{~mm}$ 이기 때문에 굵은골재의 날카로운 모서리가 훍시멘 트 혼합체를 분쇄하여 혼합을 잘되게 하는 장점이 있 다. 디자인 중심으로 볼 때, $5 \mathrm{~mm}$ 이상의 굵은골재 사 용량은 최대 $50 \%$ 이내의 범위가 적당한다. 즉, 잔골재 + 굵은골재 중량의 $20 \sim 50 \%$ 범위에서 굵은골재를 사 용하는 것이 강도와 디자인에서 적당하다. 압축강도 는 굵은골재 최대치수 $5 \mathrm{~mm}$ 공시체가 $15.8 \mathrm{MPa}, 13$ $\mathrm{mm}$ 공시체가 $18.0 \mathrm{MPa}, 25 \mathrm{~mm}$ 공시체가 $24.0 \mathrm{MPa}$ 으로 나타났다. 굵은골재 최대치수 $5 \mathrm{~mm}$ 의 공시체는 공시체 하부가 다공질의 상태로서 강도가 낮게 나타 났다.

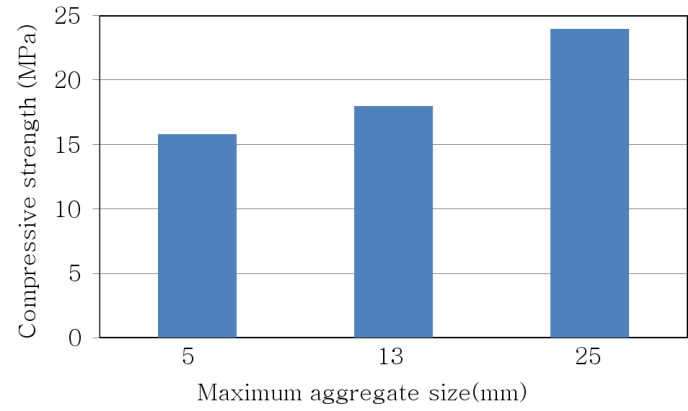

Fig. 3. 28-day sealed compressive strength versus maximum aggregate size.

포틀랜드시멘트의 수화가 진행되면 포졸란 반응에 의하여 칼슘이온이 실리카와 결합하여 규산칼슘수화 물(Calcium-Silicate-Hydrate; C-S-H)과 수산화칼슘 (Calcium Hydroxide; $\mathrm{CH}$ )을 동시에 형성한다. 수산 화칼슘은 규산칼슘수화물보다 약하며 결정이 크게 성 장하고 골재의 표면과 평행하게 배열하려는 성질이 강할 경우 쉽게 쪼개진다. 실리카흠은 수산화칼슘과 반응하여 보다 많은 규산칼슘수화물을 생성하고 규산 칼슘수화물은 강도에 기여하기 때문에 최종 수화물의 조직이 치밀해지고 강도가 높아지게 된다(Holland, 2005). 실리카훔을 시멘트의 $5 \%, 10 \%, 15 \%$ 범위에서 사용한 공시체의 압축강도 특성을 Fig. 4 에 나타내었 다. 실리카흠을 시멘트의 $5 \%$ 추가 사용한 공시의 압 축강도는 $16.9 \mathrm{MPa}, 10 \%$ 추가한 공시체는 $18.2 \mathrm{MPa}$, $15 \%$ 추가한 공시체는 $18.7 \mathrm{MPa}$ 로 나타났다. 실리카 흠을 $5 \%$ 사용한 공시체는 하부에 다공이 심하게 발생 하여 강도가 낮게 나타난 것으로 판단된다. 실리카흠 을 $15 \%$ 사용한 공시체의 하층부도 일부 다공이 발생 하였다. 따라서, 실리카흠은 $10 \%$ 범위에서 사용하는 것이 바람직하다. 실리카흠이 사용되면 물의 보습작 용으로 인해 원래 사용되는 물의 $10 \sim 30 \%$ 범위에서 추가로 필요하게 된다. 이렇게 추가 공급된 물은 시멘 트의 수화반응을 높여서 소일콘크리트의 강도를 높여 주는 역할을 하는 것으로 판단된다. 


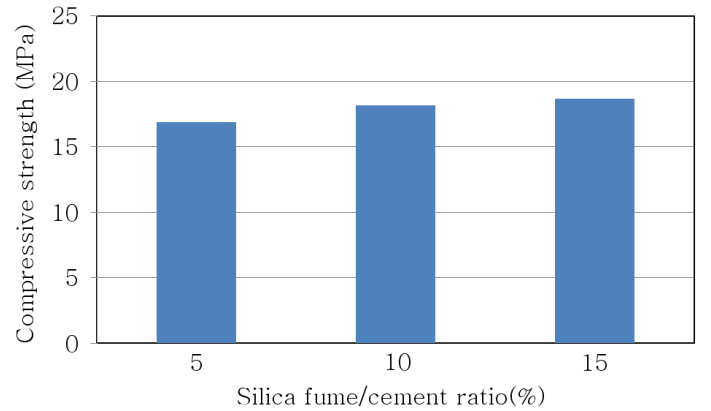

Fig. 4. 28-day sealed compressive strength versus ratio of silica fume to cement.

배합에 사용된 물의 범위는 물(결합재비 기준으로 물의 사용량을 적게 $(20 \%)$, 적당히 $(25 \%)$, 많이 $(30 \%)$ 로 설정한 경우를 가정하여 압축강도에 주는 영향을 Fig. 5에 나타내었다. 물의 양이 적은 물/결합재비 $20 \%$ 공시체는 수화반응이 안된 부분이 많아서 전체 적으로 회색을 나타내었다. 압축강도는 $11.3 \mathrm{MPa}$ 로 낮게 나타났다. 물/결합재비 $25 \%$ 공시체는 압축강도 $18.8 \mathrm{MPa}$ 이며, 물/결합재비 $30 \%$ 공시체는 압축강도 $19.8 \mathrm{MPa}$ 로 나타났다. 물의 사용범위는 $25 \pm 5 \%$ 범위 인데, 물의 사용이 적게 되면, 혼합과 시공은 쉽지만, 성형이 잘 안 되는 문제점이 발생한다. 반대로 물의 사 용량이 많으면 혼합이 어렵고 시공과정에 롤러에 붙 기 때문에 시공이 어려운 단점이 있다. 물의 단위사용 량은 휽시멘트 혼합체를 손으로 가볍게 쥐었을 때 부 서지지 않고 성형이 되는 최소한의 물 사용량이 가장 적당하다. 대략, 물/시멘트비 $=25 \%$ 범위이나, 현장에
서 화산토의 함수비가 불일정하기 때문에 손 감각으 로 물의 량을 결정하는 것이 합리적이다.

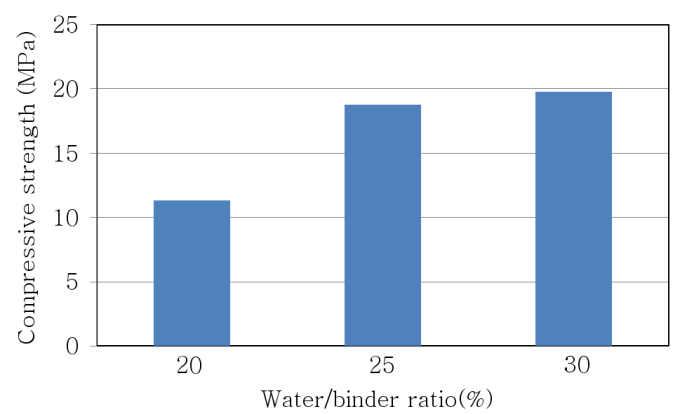

Fig. 5. 28-day sealed compressive strength versus ratio of water to binder.

Fig. 6에 시편의 표면을 확대 촬영한 사진을 나타내 고 있다. Fig. 6 (a) 시편은 다짐이 불량한 경우를 나타 내고 (b) 시편은 다짐이 잘된 경우를 나타내고 있다. 다짐 상태에 따라 훍포장체의 내부와 외부의 공극에 차이가 있고, 강도도 큰 차이를 나타낸다.

\section{2. 현장시공}

현장시공은 2010 년 4 월 1 일부터 10 월 8 일까지 제 주특별자치도 제주시 교래리 소재의 제주돌문화공원 야외 동선공사를 대상으로 실시하였다(Jeju Stone Park, 2010). 훍포장 조성물의 배합은 Table 5 에 나타 내었다. 제조방법은 백호우 $\left(0.8 \mathrm{~m}^{3}\right)$ 로 시멘트+실리카 흄+화산토 1 차 건비빔을 실시한 후(Fig. 7 (a)), 1 차 건

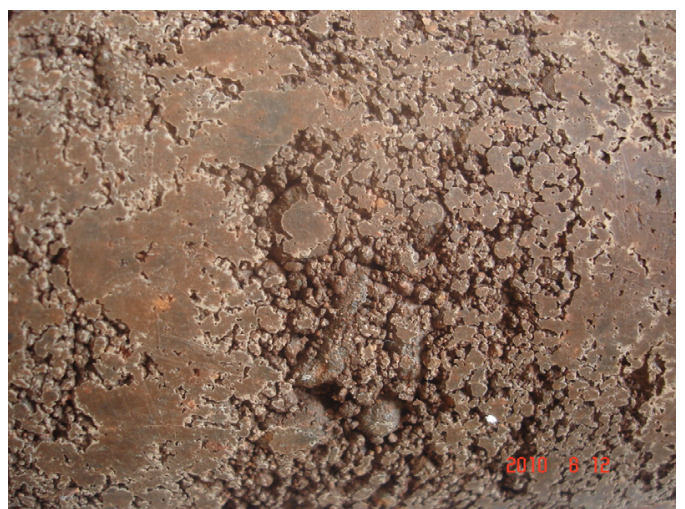

(a)

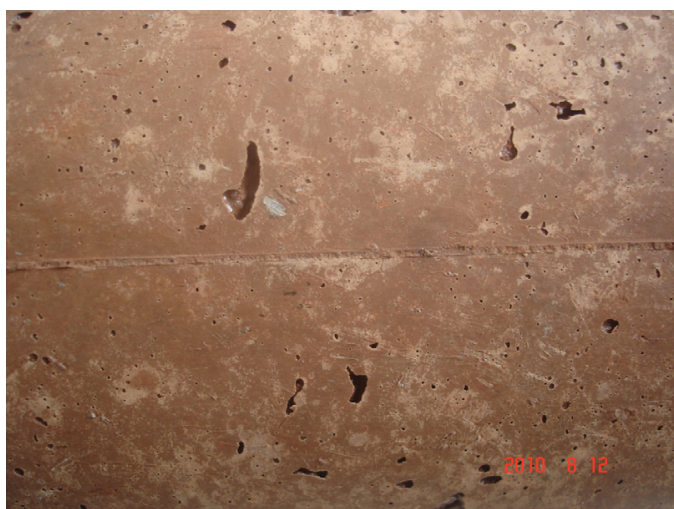

(b)

Fig. 6. Photographs of soil concrete surface. 
Table 5. Mixture proportion details of soil concrete(Unit : $\left.\mathrm{kg} / \mathrm{m}^{3}\right)$

\begin{tabular}{cccc}
\hline Cement & Silica fume & Aggregate & Water(Polymer) \\
\hline \hline 400 & 40 & 1760 & $100(10)$ \\
\hline
\end{tabular}

비빔 혼합물 + 물을 드럼식 믹서기 $\left(1 \mathrm{~m}^{3}\right)$ 를 이용하여 2차 비빔을 실시하고(Fig. 7 (b)), 트럭(5 ton)을 이용 하여 운반하는(Fig. 7 (c)) 방식으로 진행하였다. 시공 방법은 트럭에 의한 포설 후에 인력으로 면고르기를 실시한 후(Fig. 7 (d)), 롤라(1 ton)를 이용하여 다짐을 한 후(Fig. 7 (e)), 비닐과 부직포를 이용하여 양생하는 (Fig. 7 (f)) 순서로 시공하였다. 시공과정에서 흙포장 조성물의 표면이 건조해지는 것을 방지하기 위하여 물 조리게를 이용하여 물을 살포하는 방식을 사용하 였다. 시공순서를 요약하면, 1 차 건비빔 $\rightarrow 2$ 차 비빔 $\rightarrow$ 운반 $($ 트럭 $) \rightarrow$ 포설(인력) $\rightarrow$ 다짐(장비 $) \rightarrow$ 비닐(부 직포 $) \rightarrow$ 양생 $\rightarrow$ 교통개방 순서이다.

도로포장이 주변환경과 조화를 이루기 위해서는 흙 포장의 형상과 질감이 자연상태의 흙길과 동일하여야 한다. 따라서, 흙포장 측면에 거푸집을 제거하여 주변 의 흙길과 구분이 없도록 해야 하나, 흙포장의 좌우측 면은 다짐이 용이하지 않기 때문에 파손에 매우 취약
하다. 따라서, 훍포장 표면의 다짐을 최대다짐밀도의 $95 \%$ 이상 충분히 다지고, 단위체적당 $10 \mathrm{~kg}$ 의 콘크 리트폴리머를 배합수와 혼합하여 사용하여 인장강도 의 증진을 유도하였고, 좌우측면 부위는 상대적으로 물의 살포를 많이 하여 습식이 되도록 하였다. 흙포장 시공과정에서 축적된 시공기술을 Fig. 8에 나타내었 다. Fig. 8 (a)와 같이 경계석 없이 시공하여 주변의 흙 바닥과 일체감을 주도록 하였다. Fig. 8 (b)는 훍포장 체의 표면이 습윤상태를 유지하도록 가수를 하는 공 정이고, Fig. 8 (c)와 같이 흙포장체 표면에 비닐을 덮 고 그 상부에 롤라다짐을 시공하여 훍콘크리트가 롤 라에 붙지 않도록 하였다. Fig. 8 (d)는 부직포를 사용 하여 표면을 보온 양생하는 공정으로서 표면의 강도 증진에 유리하였다. 건조수축 줄눈을 시공하지 않고 자연스러운 균열이 발생하도록 유도하였다. 보행자도 로 용도이지만, 유지보수를 목적으로 한 대형차의 통 행이 예상되므로 압축강도가 $18 \mathrm{MPa}$ 이상 발휘하여 야 한다. 따라서, 흙포장체의 두께가 $15 \mathrm{~cm}$ 가 되도록 하였다. 실내에 시공하는 경우에는 $10 \mathrm{~cm}$ 범위가 적 당하다고 판단된다. 최종 완료된 흙포장의 전경사진 은 Fig. 9 에 나타내었다. Fig. 9 (a)와 Fig. 9 (b)는 보행 자도로를 나타낸 것이고, Fig. 9 (c)와 Fig. 9 (d)는 오

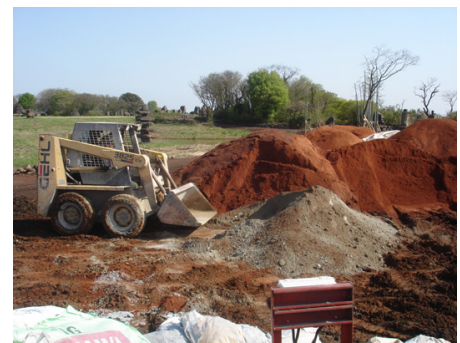

(a)

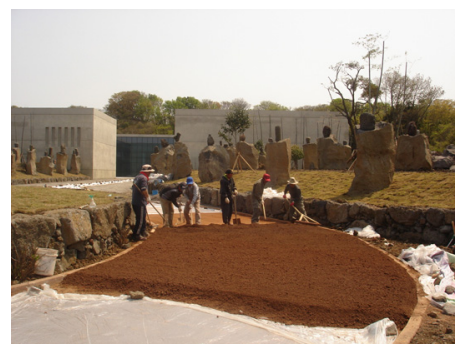

(d)

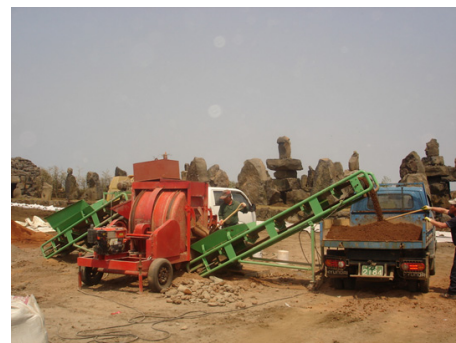

(b)

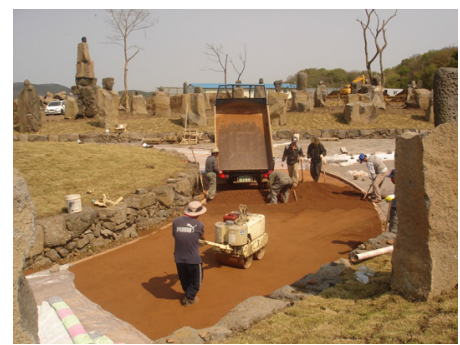

(e)

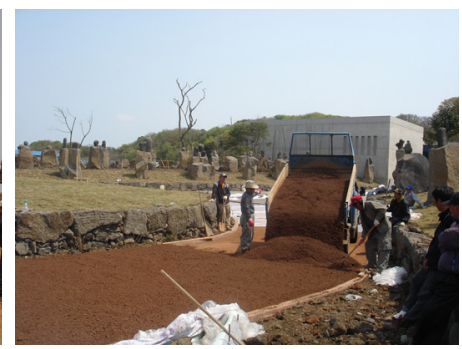

(c)

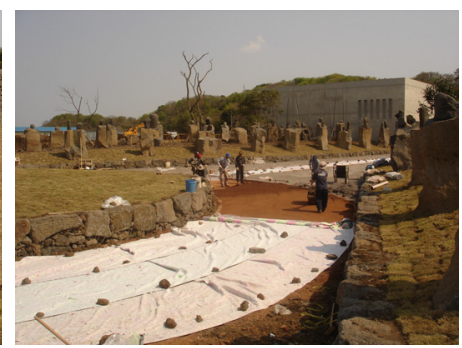

(f)

Fig. 7. Photographs of construction process. 
백장군갤러리의 진입도로를 나타낸 것이다. 화산토를 사용한 흙포장은 제주의 독특한 자연환경과 조화를 잘 이루는 것으로 판단된다. 색상의 측정은 색차계 (color difference meter) 미놀타 CR-200으로 측정하 였으며, 측색에 있어서 태양의 영향은 고려하지 않았 으며 얼룩 등은 무시하였다. 표면의 색상을 측정한 결 과 4.4 5.3의 YR계를, 명도는 3.8 5.2의 중명도를, 채도는 3.2 4.1의 저채도를 나타내어 제주특별자치 도의 자연환경과 조화를 잘 이루는 것으로 나타났다.

\section{3. 보수방법}

시공과정 중에 배합수의 부족이나 다짐 불량에 비 롯한 예기치 못한 하자가 발생하는 경우에 Table 6과 같은 보수 모르타르를 사용하여 하자 부위를 보수 하 였다. 흙포장의 보수에 있어서 화산토 $5 \mathrm{~mm}$ 이하 +

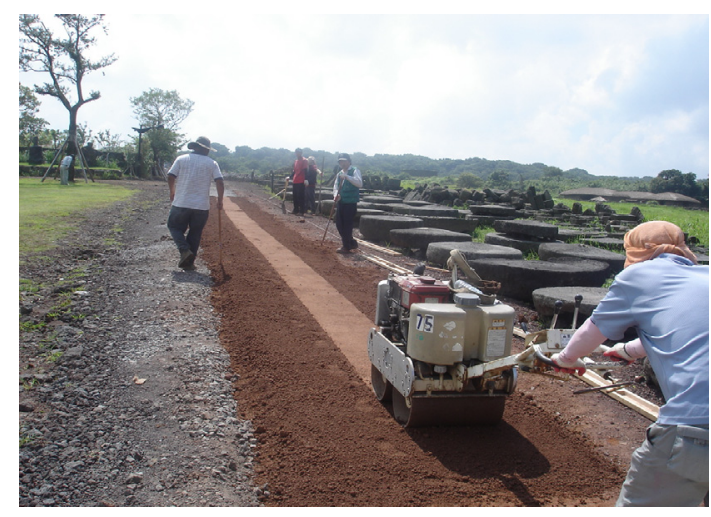

(a)

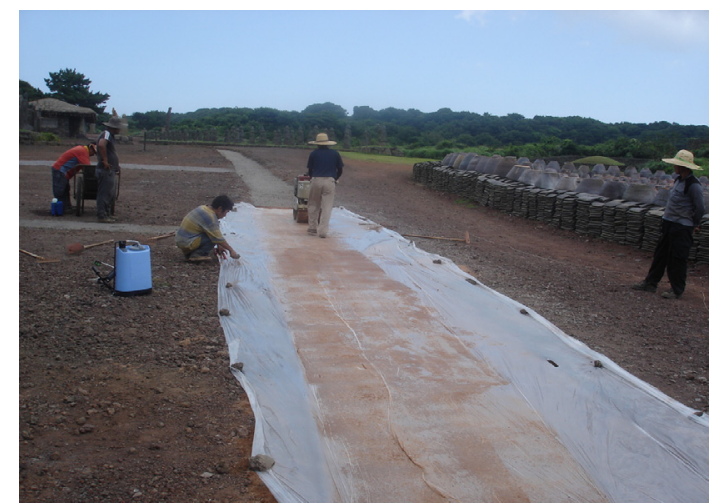

(c)
시멘트 + 콘크리트폴리머 + 물의 혼합물을 충분히 배 합한 후, 하자 부위를 표면청소 $\rightarrow$ 모르타르 덧씨우기 $\rightarrow$ 비닐을 덮고 $\rightarrow$ 흙손 또는 롤라를 사용하여 다짐 $\rightarrow$ 부직포로 덮고 $\rightarrow$ 양생 과정을 거쳐 보수하는 것을 특 징으로 한다.

Table 6. Mixture proportion details of soil mortar(Unit :

\begin{tabular}{cccc}
\multicolumn{2}{c}{$\mathrm{kg} / \mathrm{m}^{3}$ ) } & & \\
\hline Cement & $\begin{array}{c}\text { Concrete } \\
\text { polymer }\end{array}$ & $\begin{array}{c}\text { Aggregate } \\
\text { (Max. 5 mm) }\end{array}$ & Water \\
\hline \hline 500 & 50 & 1500 & 250 \\
\hline
\end{tabular}

\section{4. 결 론}

본 연구는 제주도 석산 부산물인 화산토를 사용한 흙 포장에 대한 연구로서 실험실 규모의 강도 실험과 현

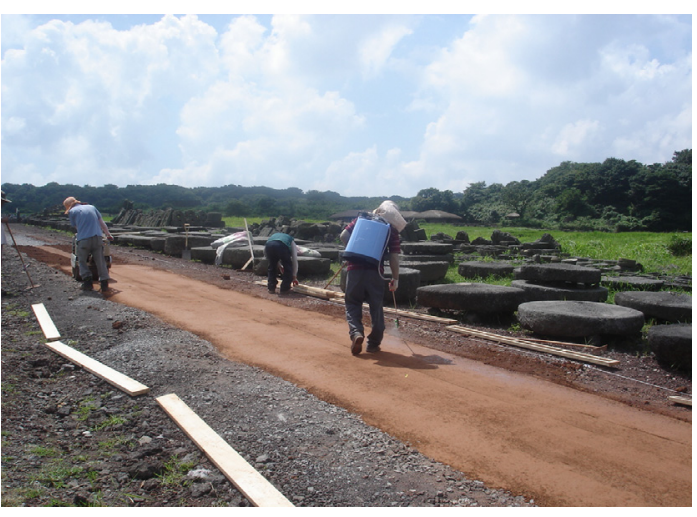

(b)

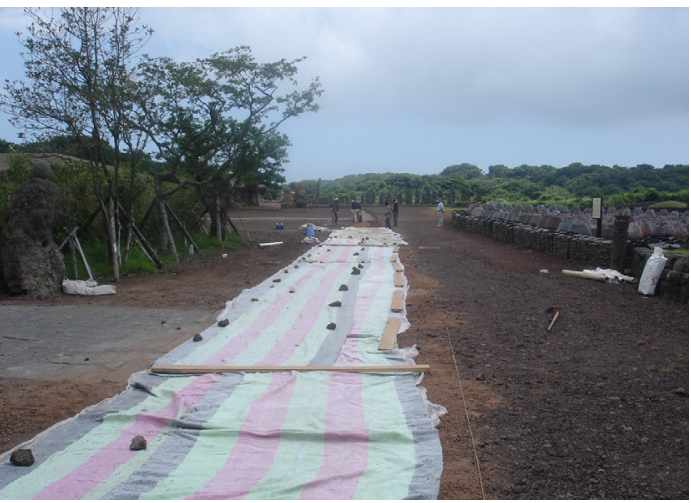

(d)

Fig. 8. Photographs of construction techniques. 


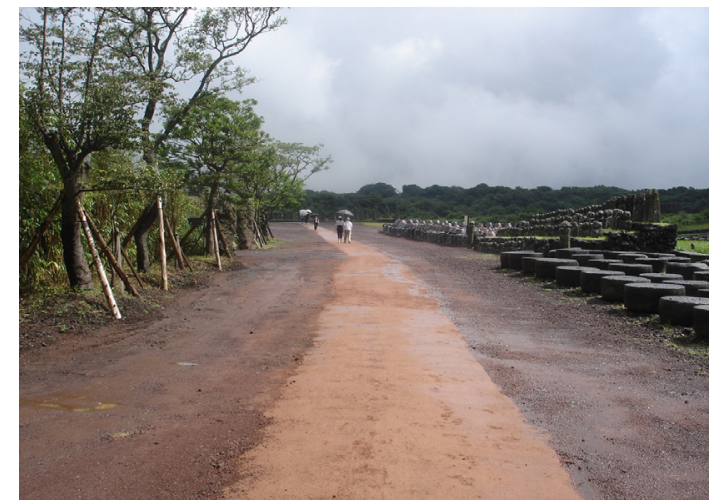

(a)

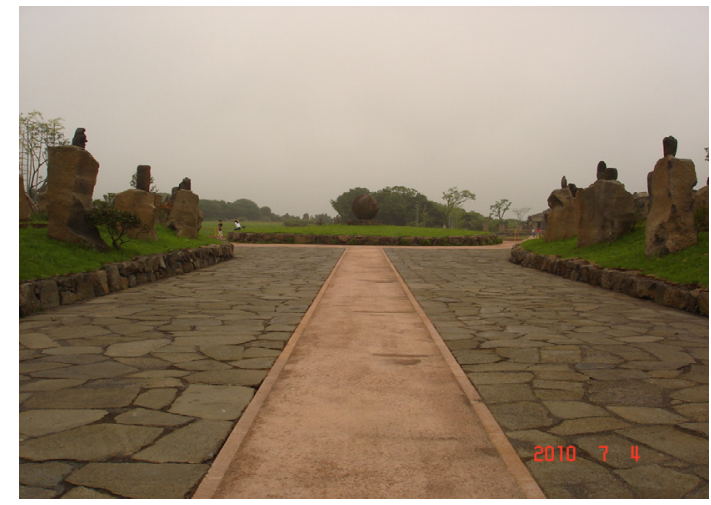

(c)

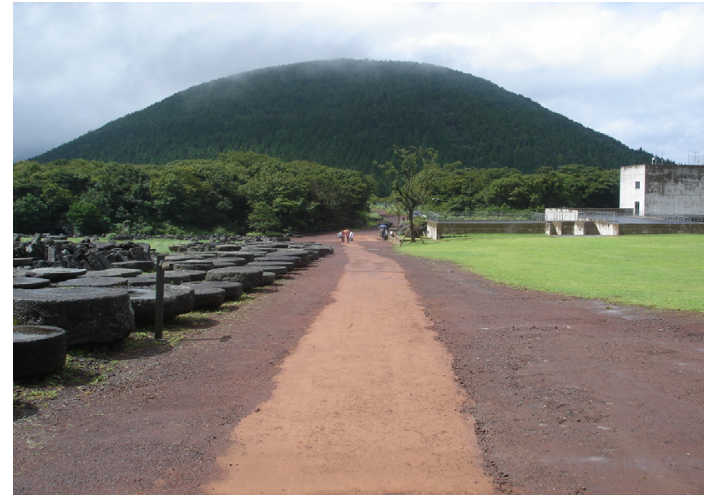

(b)

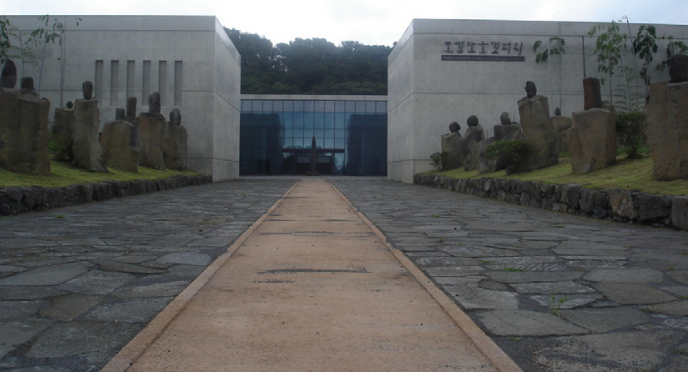

(d)

Fig. 9. Photographs of completed soil concrete pavement.

장 적용 시험시공을 실시하였다. 흙포장의 품질은 훍 의 특성, 결합재의 비율, 다짐에너지, 혼화재의 비율, 배합수의 비율, 믹서기의 성능, 그리고 시공능력 등 다 양한 변수에 영향을 받는 것으로 나타났다. 연구결과 를 요약하면 다음과 같다.

1) 흙포장에 사용되는 화산토와 결합재의 배합비율 은 $4: 1$ 이 적당하며, 화산토의 최대치수와 입도는 13 $\mathrm{mm}$ 의 혼합골재가 적당하고, 혼화재로 사용된 실리카 흄은 시멘트의 $10 \%$ 범위가 합리적이며, 물/결합재비 는 $25 \%$ 로 시공가능한 범위에서 물을 최대한 많이 사 용하는 것이 유리하다.

2) 종래의 일반콘크리트를 사용한 다짐공법에서는 다짐을 하더라도 체적의 수축이 $10 \pm 5 \%$ 내외로 작지 만, 화산토를 사용한 소일콘크리트의 경우에는 $20 \pm 10 \%$
범위로 매우 크다. 따라서, 시공과정에서 체적의 수축 에 대하여 사전에 고려해야 한다. 도로포장의 시공에 있어서 화산토를 사용한 소일콘크리트의 1 일 생산량 은 $40 \pm 10 \mathrm{~m}^{3}$ 가 적당한 것으로 나타났다.

3) 도로포장의 두께는 최소 $10 \mathrm{~cm}$ 에서 최대 $15 \mathrm{~cm}$ 의 범위가 적당하고, $15 \mathrm{~cm}$ 두께의 경우 2 층으로 분리 하여 다짐하는 것이 좋다. 화산토 콘크리트 타설 후 습 기가 대기중으로 빠져나가 건조되는 것을 방지하기 위하여 비닐을 이용하여 덮어주는 것이 바람직하다. 양생과정에서도 공기의 흐름을 차단하기 위해 비닐을 이용하여 완전히 밀폐된 공간을 만들어 주어야 한다. 최소 3 일간의 양생 기간을 거쳐야 하고 바람직하게는 5 일의 양생기간을 거쳐야 한다.

4) 현재, 화산토를 사용한 소일콘크리트의 압축강 도가 $18 \pm 5 \mathrm{MPa}$ 범위이다. 향후, $27 \mathrm{MPa}$ 이상의 고 
강도 소일콘크리트에 대한 연구와 화산토를 사용한 옹벽, 수로, 벽돌 등과 같은 소일콘크리트 2 차 제품에 대한 연구가 추가로 수행되어야 한다고 판단된다.

\section{참 고 문 헌}

Holland, T. C., 2005, Silica fume user's manual, Federal Highway Administration, 183.

Hong, C. H., 2009, Physical properties of soil concrete using volcaniclastic and the application to roadway, Journal of the Environmental Sciences, 18(9), 993-1000.

Hong, C. H., 2010, Crack characteristics of soil concrete using volcaniclastic and the crack repair method, Journal of the Environmental Sciences, 19(6), 737-746.

Hong, C. H., Kim, M. H., Jeong, D. Y., 2009 , Development of pavement and construction materials using volcaniclastic for public design, Magazine of the Korea Concrete Institute, 22(3), 83-87.

Jeju Stone Park, 2010, http://www.jejustonepark.com. Jeong, D. Y., Choi, K. R., Kim, M. H., Hong, C. H., 2007, An experimental study on development of eco-friendly color concrete using industrial waste red mud, Journal of the Environmental Sciences, 16(8), 929-939.

Jung, H. S., Jang, C. H., An, B. J., Chun, B. S., 2009, A study on environmentally friendly soil pavement materials using weathered soil and inorganic binder, KGES Journal of Geo-environmental Engineering, 10(4), 25-31.

Lee, C. O., Hong, S. S., Lee, B. T., Kim, G. S., Yun, H. S., 2006, Spatial distribution of the dimension stone quarries in Korea, Journal of the Petrological Society of Korea, 15(3), 119-169.

Ministry for Food, Agriculture, Forestry and Fisheries, 2009, Framing an application model for environment color to make rural landscape image, Research Report 2009-1-12. 